Short communication

\title{
CASEOUS LYMPHADENITIS IN SHEEP IN THE FALKLAND ISLANDS
}

\author{
LISTOS Piotr ${ }^{1 *}$, GRYZINSKA Magdalena ${ }^{2}$, MARTYCHIEWICZ Marcin ${ }^{3}$, \\ POINTING Stephen ${ }^{3}$, BARTON Albrecht ${ }^{1}$, DYLEWSKA Malgorzata ${ }^{2}$
}

\author{
${ }^{1}$ Department of Pathological Anatomy, Faculty of Veterinary Medicine, University of Life Sciences, ul. \\ Gleboka 30, 20-612 Lublin, Poland \\ ${ }^{2}$ Department of Biological Basis of Animal Production, Faculty of Biology and Animal Breeding, \\ University of Life Sciences, ul. Akademicka 13, 20-950 Lublin, Poland \\ ${ }^{3}$ Department of Agriculture, Stanley, Falkland Islands
}

(Received 06 April; Accepted 29 June 2016)

\begin{abstract}
Caseous lymphadenitis (CLA), also called pseudotuberculosis, is a chronic and highly infectious disease of sheep and goats, subject to obligatory registration in the European Union. The EU law also applies to special territories, which include the Falkland Islands. On the Falkland Islands 99\% of sheep and goats are slaughtered in one slaughterhouse, overseen by veterinary authorities, and approved for export to EU countries (mainly the UK). The export season begins about the middle of January and usually lasts 3-4 months. In the years 2013-2015 were examined 162317 sheep, including 39971 lambs, 35357 yearlings and 86989 mature rams. During the study lung tissue clippings were collected. During the 2013 season lesions were observed in 8025 of animals $(13.9 \%$ CLA). In 2014 lesions were noted in 7716 with CLA accounting for 13.91\% and in 2015 lesions were noted in 5743 with CLA accounting for $11.7 \%$. Further analysis of cases of CLA on the Falkland Islands seems interesting, as they are British overseas territories and therefore part of the European Union.
\end{abstract}

Key words: caseous lymphadenitis - CLA, pseudotuberculosis, sheep

\section{INTRODUCTION}

The disease is induced by Corynebacterium pseudotuberculosis, a Gram-positive bacillus. It causes abscesses in the skin, with an onion-ring appearance in cross-section, as well as in the superficial or deep lymph nodes and in the internal organs. The lesions can be observed in animals at the age of just 6 months. Corynebacterium pseudotuberculosis is a pathogenic bacterium which, besides sheep and goats, also occurs in camels, buffalo, wild ruminants, horses, monkeys, pigs and birds [1]. The main sources of infection include sick animals, carriers, faeces, pus, tools and instruments used in animal care, livestock housing, soil, and fodder contaminated by C. pseudotuberculosis.

*Corresponding author: e-mail: piotr.listos@up.lublin.pl 
Animals usually become infected through skin wounds sustained during shearing (in the vicinity of the neck, shoulders or flank) or fighting in the herd (injuries on the head or front of the body), or following castration. In neonates, an umbilical cord contaminated with secretion from a skin abscess may be the route of infection. The respiratory system is considered less important as a site of infection, but bacteria can enter the lungs by this route and cause lesions in the form of diffuse abscesses. Infections can also take place during the foetal period, so that lambs are born with the disease. In this case most of the lesions are located on the lungs and in the lymph nodes of the chest. Similar lesions may be observed in the case of subcutaneous infection, with lesions distant from the site of infection [2].

\section{MATERIAL AND METHODS}

The material was the documentation (database of epizootic and photographs of cases) of the slaughterhouse in Stanley, Falkland Islands. In the years 2013-2015 were examined 162317 sheep, including 39971 lambs, 35357 yearlings and 86989 mature rams. The histological study was on the collected clippings of lung tissue. The tissue sections were stained with haematoxylin and eosin (H\&E) and photodocumented under a light microscope.

\section{RESULTS AND DISCUSION}

Post-slaughter examination revealed abscesses in such organs as the heart, pericardium or spleen (Figure 1). Both clinical forms of the disease occur in both sheep and goats, but the superficial form is believed to be more common in goats, while the form affecting the internal organs is more common in sheep. Table 1 presents the numbers of sheep slaughtered in the Falkland Islands in the years 2013-2015. During postslaughter analysis at the slaughterhouse, mixed forms of infection were observed, with predominance of lesions in the superficial lymph nodes. Histopathological examination of lung tissue (H\&E) revealed a central focus of caseous necrosis, with prominent karyorrhexis necrosis. The necrosis was surrounded by giant cells, and more peripherally, by lymphocytes and nonspecific granulomatous tissue. (Figure 2).

Caseous lymphadenitis may occur in two forms. The first (acute - superficial) is manifested as suppurative enlargement of the subcutaneous lymph nodes. In young, sensitive animals, infection leads to acute toxaemia with respiratory symptoms, appetite loss, elevated temperature, ruminal atony, jaundice, anaemia and haemoglobinuria. It usually affects the lymph nodes near the head (intermandibular, parotid, retropharyngeal and cervical) and those associated with the limbs (prescapular, prefemoral and supramammary). The animals die within 48 hours after infection. The second form, probably caused by long-term weakness (associated with changes in internal organs and lymph nodes) is milder, with body temperature rising to 39.5-40.8 ${ }^{\circ} \mathrm{C}$. It involves an inflammatory response at the site of infection, pain, and swelling 
of regional lymph nodes. The internal organs affected by abscesses are the lungs and pulmonary lymph nodes, kidneys, liver and mesenteric lymph nodes. After some time the symptoms remit and the infection takes a chronic form, which is more difficult to diagnose. In this case the animals become carriers, with abscesses in their internal organs. According to the literature, cases of a subacute form of CLA have been noted as well [3].

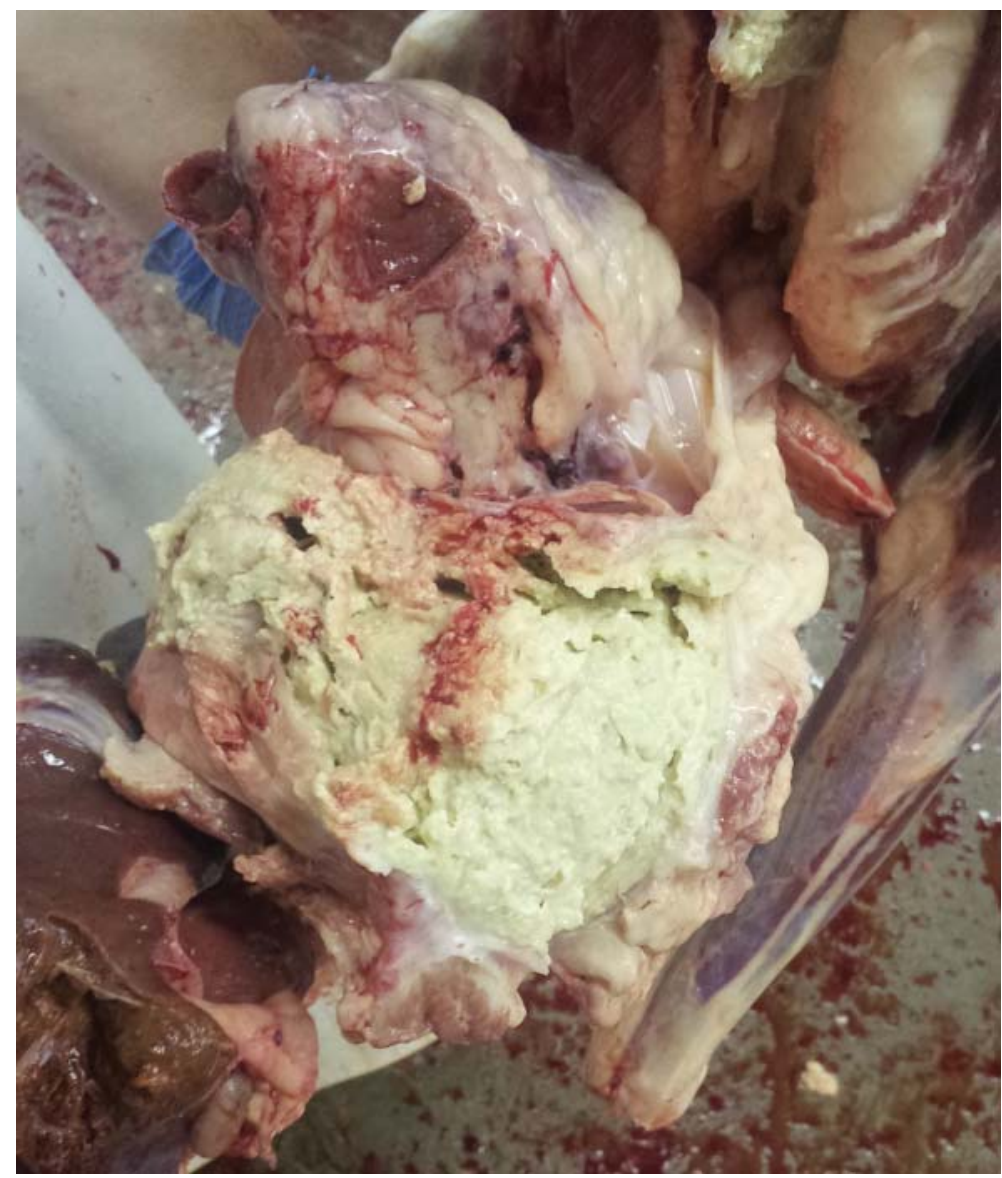

Figure 1. Abscess encapsulated with prominent connective tissue in pericardium

The mild form can be further divided into superficial and internal forms. The superficial form is manifested by abscesses and enlarged subcutaneous lymph nodes. Most commonly affected are the parotid, submandibular or prescapular lymph nodes, or less often the inguinal, popliteal or supramammary lymph nodes [4]. The other, internal form is associated with lesions in the internal organs and lymph nodes. It can be caused by long-term weakness. 
Table 1. Number of sheep slaughtered in the Falkland Islands in 2013-2015

\begin{tabular}{ccccc}
\hline Year & Type & $\begin{array}{c}\text { Number of } \\
\text { slaughtered } \\
\text { sheep }\end{array}$ & $\begin{array}{c}\text { Number of } \\
\text { sheep with } \\
\text { CLA }\end{array}$ & $\begin{array}{c}\text { Percentage of } \\
\text { sheep with CLA } \\
\text { (\%) }\end{array}$ \\
\hline \multirow{2}{*}{2013} & Sheep Lamb & 17,460 & 24 & 0.14 \\
& Sheep Yearling & 10,688 & 132 & 1.24 \\
& Sheep Mutton & 29,596 & 7,869 & 26.59 \\
2014 & All & 57,744 & 8,025 & 13.90 \\
& Sheep Lamb & 16,322 & 13 & 0.08 \\
& Sheep Yearling & 12,049 & 268 & 2.22 \\
2015 & Sheep Mutton & 27,100 & 7,435 & 27.44 \\
& All & 55,471 & 7,716 & 13.91 \\
\hline \multirow{2}{*}{$2013-2015$} & Sheep Lamb & 6,189 & 4 & 0.06 \\
& Sheep Yearling & 12,620 & 243 & 1.93 \\
& Sheep Mutton & 30,293 & 5,496 & 18.14 \\
& All & 49,102 & 5,743 & 11.70 \\
\hline
\end{tabular}

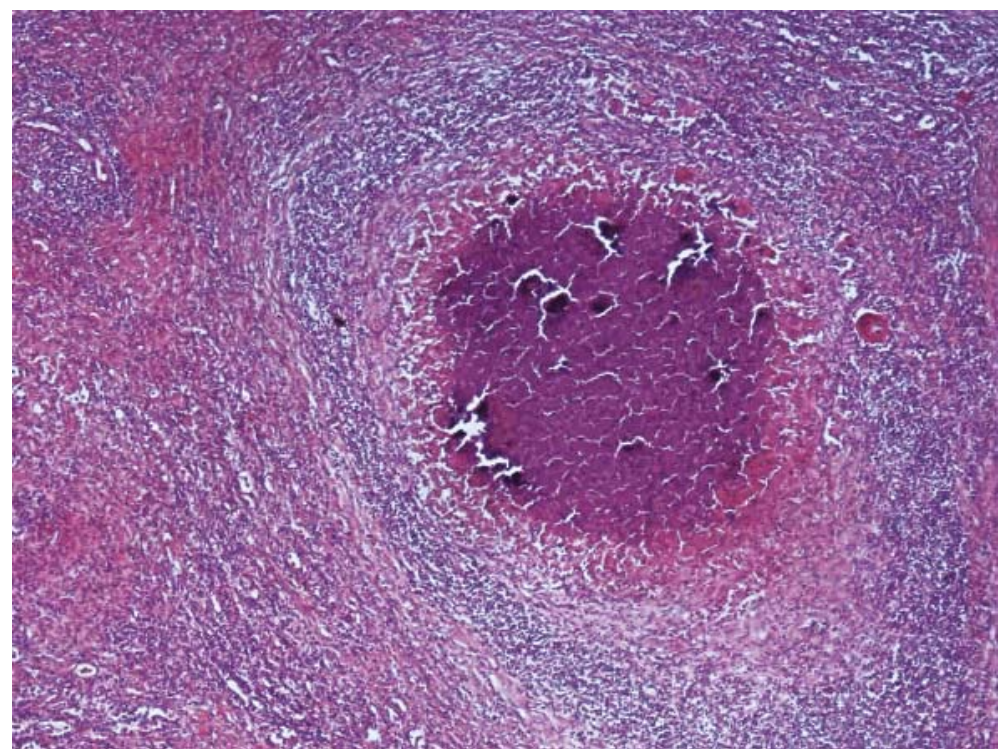

Figure 2. Focus of coagulative necrosis within granuloma of lung tissue (HE; $40 \mathrm{x}$ )

The internal organs affected by abscesses include the lungs and pulmonary lymph nodes, mesenteric lymph nodes, kidneys, liver, heart, pericardium, and spleen. Both forms of the disease occur in both sheep and goats, but the superficial form is thought to be more common in goats, and the form involving the internal organs in sheep. During the course of the disease enlargement of one or more superficial lymph nodes 
is observed; they are painless and filled with cream-coloured or greenish pus with a thick, sticky consistency. In sheep the pus has a thick, dry consistency with the appearance of onion skin. These lesions may persist for a long time - months or even years - in the form of painless tumour-like lesions which grow slowly until they burst and release a secretion containing bacteria into the external environment [5]. The animals do not display additional clinical disease symptoms except for cases in which the position of the abscess impedes breathing or swallowing. Development of the disease leads to weight loss and a gradual decline in body condition.

Diagnosis of the disease involves clinical examination, particularly of the lymph nodes, in combination with the medical history and information on the epidemiological status of the region. Microbiological testing for Corynebacterium psendotuberculosis in the discharge from the abscess, collected from the lymph node, will confirm (or rule out) the initial diagnosis. Corynebacterium pseudotuberculosis is generally easy to isolate from the collected material, which may at the same time contain other pyogenic bacteria, such as Actinomyces pyogenes, Staphylococcus aureus and Pasteurella multocida. In cases of latent or chronic states and carriage, allergy tests show an increased antibody titre in infected individuals which do not yet display clinical symptoms. Tests can be based on the titre of the cell wall antigen or indicators of the immune response to exotoxins, which are used more often in practice [6]. Routine diagnostic tests may also include agglutination, microagglutination [7], tube agglutination, indirect haemagglutination, complement fixation, agar gel precipitation, haemolysis inhibition and synergistic haemolysis inhibition [8]. In most cases, however, ELISA assays are used for the diagnosis of large numbers of animals [6,9]. These tests have high sensitivity of $86.3 \%$ and specificity of 82.1\% [8]. Immunoblotting and PCR are used for additional verification.

When a negative result is obtained twice, the individuals are considered to be free of infection. After 12 months each animal should be tested again and subsequently every two years. This method is considered to be effective in eliminating the disease from the herd [10].

Infected animals are not treated, because the abscesses are encapsulated and antibiotics can only penetrate them to a very small degree. Although the bacteria are susceptible to penicillin, macrolides, tetracycline, cefalosporin, lincomycin, chloramphenicol and rifampicin, the effects are imperceptible and treatment is ineffective, allowing the disease to continue to spread in the herd. Local antibiotic treatment within the abscess has almost no effect in fighting the infection. Therefore animals with visible clinical symptoms as well as carriers should be isolated from the rest of the herd. In the case of superficial abscesses on the skin the abscess is surgically removed or opened and washed with 7\% iodine solution. However, this method is not always fully successful, as the disease process may recur.

\section{Acknowledgements}

We thank Ms. Sara Wild for translating this manuscript. 


\section{Authors' contributions}

LP have made substantial contributions to conception and design, acquisition of data, analysis and interpretation of data; have been involved in drafting the manuscript or revising it critically for important intellectual content; have given final approval of the version to be published; agree to be accountable for all aspects of the work in ensuring that questions related to the accuracy or integrity of any part of the work are appropriately investigated and resolved. GM paricipated in its design and coordination and helped to draft the manuscript. MM have been involved ind drafting the manuscript and revising it critically for important intellectual content. PS have made substantial contributions to conception and acquisition of data. BA have been involved in drafting the manuscript. DM have given final approval of the version to be published.

\section{Declaration of conflicting interests}

The author(s) declared no potential conflicts of interest with respect to the research, authorship, and/or publication of this article.

\section{REFERENCES}

1. Sood NK, Sandhu BS, Gupta K, Narang D, Vasudeva K, Singh ND: Mesenteric caseous lymphadenitis in a cow calf caused by Corynebacterium pseudotuberculosis: a case report. Veterinarni Medicina 2012, 57: 371-375.

2. Paton M, Rose I, Hart R, Sutherland S, Mercy A, Ellis T: Post-shearing management affects the seroincidence of Corynebacterium pseudotuberculosis infection in sheep flocks. Prev Vet Med 1996, 26:275-284.

3. O'Reilly KM, Medley GF, Green LE: The control of Corynebacterium pseudotuberculosis infection in sheep flocks: a mathematical model of the impact of vaccination, serological testing, clinical examination and lancing of abscesses. Prev Vet Med 2010, 95:115-26.

4. Oreiby AF, Hegazy YM, Osman SA, Ghanem YM, Al-Gaabary MH: Caseous lymphadenitis in small ruminants in Egypt Clinical, epidemiological and prophylactic aspects. Tierärztliche Praxis Großtiere 2014, 5:271-277.

5. Manning EJB, Cushing, HF, Hietala S, Wolf CB: Impact of Corynebacterium pseudotuberculosis infection on serologic surveillance for Johne's disease in goats. J Vet Diagn Invest 2007, 19:187-190.

6. Figueiredo Castro Nassar A, Miyashiroa S, Gregori F, Piatti RM, Terezinha Daniel G, Gregory L: Standardization of an enzyme-linked immunosorbent assay (ELISA) for detection of antibodies anti-Corynebacterium pseudotuberculosis in sheep. Small Rumin Res 2014, 116: 229-232.

7. Menzies PI, Muckle CA: The use of a microagglutination assay for the detection of antibodies to Corynebacterium pseudotuberculosis in naturally infected sheep and goat flocks. Can J Vet Res 1989, 53:313-318. 
8. ter Laak EA, Bosch J, Bijl GC, Schreuder BE: Double-antibody sandwich enzyme-linked immunosorbent assay and immunoblot analysis used for control of caseous lymphadenitis in goats and sheep. Am J Vet Res 1992, 53:1125-1132.

9. ter Laak EA, Schreuder BE: Serological diagnosis of caseous lymphadenitis in goats and sheep. Vet Rec 1991, 128:436.

10. Schreuder BEC, ter Laak EA, Dercksen DP: Eradication of caseous lymphadenitis in sheep with the help of a newly developed ELISA technique. Vet Rec 1994, 135:174-176.

\title{
KAZEOZNI LIMFADENITIS KOD OVACA NA FOKLANDSKIM OSTRVIMA
}

\author{
LISTOS Piotr, GRYZINSKA Magdalena, MARTYCHIEWICZ Marcin, \\ POINTING Stephen, BARTON Albrecht, DYLEWSKA Malgorzata
}

Kazeozni limfadentis (CLA), koji se naziva i pseudotuberkuloza, predstavlja hroničnu i veoma kontagioznu bolest ovaca i koza. Obolenje je obavezno za prijavljivanje u zemljama Evropske Unije, a samim tim i u tzv. specijalnim teritorijama kao što su Foklandska ostrva. Na Foklandskim ostrvima, 99\% ovaca i koza se zakolje u jednoj klanici. Trupovi bivaju pregledani od strane veterinarske inspekcije, nakon čijeg odobrenja meso može da se izveze u zemlje Evropske Unije (najvećim delom u UK). Sezona izvoza mesa počinje sredinom januara i traje obično 3-4 meseca. U periodu od 2013 do 2015, pregledano je 162317 ovaca, uključujući i 39971 jaganjaca, 35357 šilježadi i 86989 odraslih ovnova. Tokom studije, sakupljani su uzorci tkiva pluća, pri čemu je tokom sezone 2013. godine, ustanovljeno prisustvo CLA u 8025 uzoraka (13.9\%). Naredne godine, lezije u tkivima su ustanovljene kod 7716 uzoraka pri čemu je CLA ustanovljen u 13.91\% slučajeva. Tokom 2015 godine, lezije su ustanovljene kod 5743 uzoraka od kojih je 11.7\% CLA. Neophodno je da se obave dalja ispitivanja slučajeva CLA na Foklandskim ostrvima s obzirom na to da pripadaju Velikoj Britaniji, odnosno Evropskoj Uniji. 